\title{
Orbital Metastasis as Initial Clinical Presentation in a Patient of Hepatocellular Carcinoma - A Rare Case with Review of Literature
}

\author{
Sakshi Rana ${ }^{1}$ Divya Khosla ${ }^{1} \quad$ Kannan Periasamy ${ }^{1} \quad$ Rakesh Kapoor $^{1} \quad$ Sunny Bhardwaj ${ }^{2}$ \\ Renu Madan ${ }^{1}$ Shikha Goyal ${ }^{1}$ Arvind Rajwanshi
}

${ }^{1}$ Department of Radiotherapy, Regional Cancer Centre, Postgraduate Institute of Medical Education and Research, Chandigarh, India

2Department of Cytology and Gynecologic Pathology, Postgraduate Institute of Medical Education and Research, Chandigarh, India

\begin{abstract}
Address for correspondence Divya Khosla, MD Radiotherapy, Department of Radiotherapy, Regional Cancer Centre, Postgraduate Institute of Medical Education and Research, Chandigarh, India (e-mail: dr_divya_khosla@yahoo.com).
\end{abstract}

Ind J Med Paediatr Oncol 2021;42:385-389.

\begin{abstract}
Keywords

- hepatocellular

carcinoma

- metastasis

- orbital

- palliation

- radiotherapy

Orbital metastasis, as the initial clinical presentation in hepatocellular carcinoma (HCC), is a rare manifestation. A 66-year-old male patient presented with a history of protrusion of the eyeballs, double vision, and swelling over the left side of the head for 8 months. Magnetic resonance imaging of the brain with orbit revealed a heterogeneous lesion in the left frontal lobe causing its destruction with intraorbital and intracranial extension. Triphasic contrast-enhanced computed tomography was suggestive of multiple hypodense areas in both lobes of the liver. Tissue diagnosis from the liver was suggestive of HCC. A diagnosis of multifocal HCC with orbital metastasis was made. The patient was treated with palliative radiotherapy and sorafenib. Orbital metastasis in HCC is rare. Prognosis is somber in such cases. The treatment should focus on providing palliation from symptoms.
\end{abstract}

\section{Introduction}

Orbital metastases are relatively uncommon accounting for 1 to $13 \%$ of all orbital tumors and occur in 2 to $5 \%$ of cancer patients. ${ }^{1-4}$ Hepatocellular carcinoma (HCC) is an aggressive malignancy, with 50 to $75 \%$ of patients developing metastases during the course of their disease., 5 The most common sites of metastasis are the regional lymph nodes and lungs. The less common sites of distant metastases include bone, brain, adrenal glands, and skin. $5,7,8$

The common malignancies metastasizing to the orbit are breast, lung, prostate, kidney, thyroid, and gastrointestinal. ${ }^{1,9-11}$ Orbital metastasis from HCC is a rare presentation with only a handful of cases reported in the literature. Herein, we report a rare case of orbital metastasis as the initial clinical presentation in a patient with HCC with a brief review of the literature.

\section{Case Report}

A 66-year-old male patient presented with a history of protrusion of the eyeballs, double vision, and swelling over the left side of the head for 8 months. There was no history of jaundice, awareness of mass anywhere else in the body, loss of weight, and loss of appetite. On clinical examination, left eye proptosis with reduced visual acuity and conjunctival chemosis was present. A soft-tissue swelling measuring $4 \mathrm{~cm} \times 4 \mathrm{~cm}$ was present in the left frontal region and orbit. Abdominal examination revealed hepatomegaly. The differential diagnosis at this stage included primary orbital
DOI https://doi.org/ $10.1055 / \mathrm{s}-0041-1736682$ ISSN 0971-5851

\section{(c) 2021. Indian Society of Medical and Paediatric Oncology}

This is an open access article published by Thieme under the terms of the Creative Commons Attribution-NonDerivative-NonCommercial-License, permitting copying and reproduction so long as the original work is given appropriate credit. Contents may not be used for commercial purposes, or adapted, remixed, transformed or built upon. (https://creativecommons.org/licenses/by-nc-nd/4.0/).

Thieme Medical and Scientific Publishers Private Ltd. A-12, Second Floor, Sector -2, NOIDA -201301, India 
neoplasm or metastatic tumor to the orbit. Baseline investigations including hemogram and kidney function tests were normal. Bilirubin was within normal limits, but liver enzymes were raised (aspartate transaminase: $87.3 \mathrm{U} / \mathrm{L}$, alanine transaminase: $93.17 \mathrm{U} / \mathrm{L}$, and alkaline phosphatase: $223 \mathrm{U} / \mathrm{L}$ ). Serum $\alpha$ fetoprotein was found to be elevated $(1000 \mathrm{ng} / \mathrm{mL})$. Peripheral blood film examination did not show any abnormality. The patient tested positive for hepatitis $\mathrm{C}$ antibody. Magnetic resonance imaging (MRI) of the brain with orbit revealed a heterogeneous lesion in the left frontal lobe causing its destruction with intraorbital and intracranial extension ( - Fig. 1). Contrast-enhanced computed tomography of the chest was normal, and a triphasic scan of the abdomen showed multiple arterial hypervascular lesions in both lobes of the liver with washout in venous and delayed phases, suggestive of multifocal HCC. The largest lesion measured $2.5 \mathrm{~cm} \times 3.2 \mathrm{~cm}$ in the right lobe of the liver ( - Fig. 2). Multiple, small, similar arterial hypervascular lesions were seen in both lobes of the liver. Ultrasound-guided fine-needle aspiration cytology from the liver was suggestive of HCC ( - Fig. 3 ). The patient was treated with palliative radiotherapy of $30 \mathrm{~Gy}$ in 10 fractions to the left eye. The patient was subsequently started on sorafenib. MRI of the brain including the orbit was done after 3 months of radiotherapy, which revealed a significant reduction in the size of the lesion. Four months later, the patient developed lung metastasis and left iliac bone metastasis. He was given palliative radiotherapy of $20 \mathrm{~Gy}$ in five fractions to the left iliac bone, following which he had significant pain relief. The patient was given the option of second-line treatment with immune checkpoint inhibitors or second-line tyrosine kinase inhibitors, but he refused due to cost issues. The patient received intravenous zoledronic acid for 3 months. The patient is alive with progressive disease and is on palliative care.

\section{Discussion}

Metastasis to the orbit is a rare presentation in HCC. Breast constitutes the most common primary site, with 28 to $70 \%$ of orbital metastasis. ${ }^{11}$ The common presenting symptoms of orbital metastases include diminished vision, pain, proptosis, double vision, awareness of mass, and limitation of extraocular movements. The differential diagnosis includes

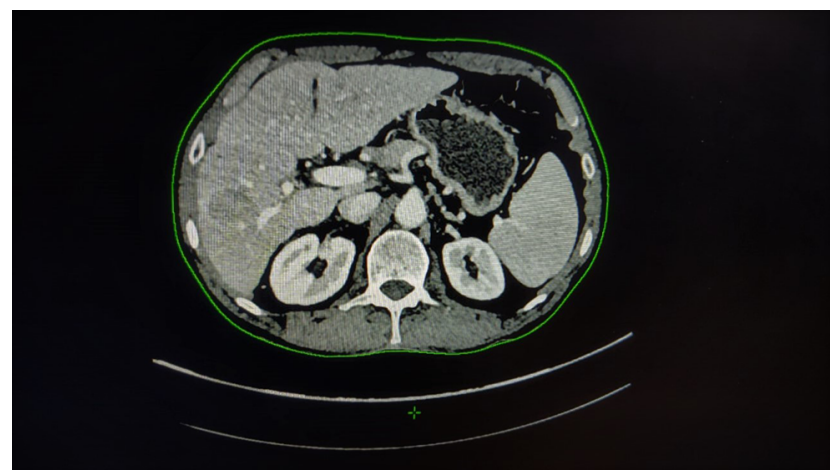

Fig. 2 Contrast-enhanced computed tomography (CECT) showing a lesion in segment $\mathrm{VI}$ of the liver with small lesions in both lobes of the liver.
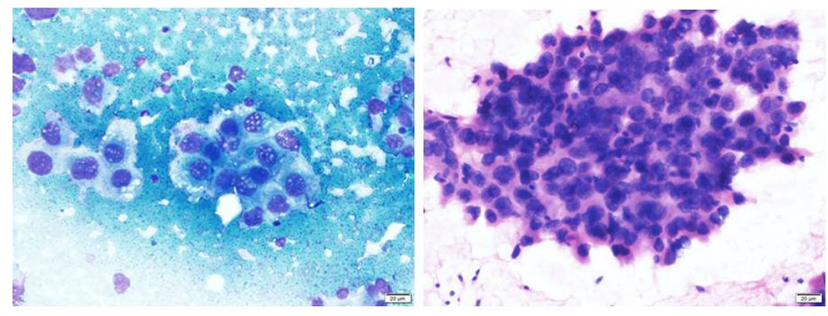

Fig. 3 The tumor cells were highly pleomorphic with coarse chromatin, prominent nucleoli, and moderate amount of cytoplasm. These tumor cells showed prominent cytoplasmic and nuclear vacuoles, and some of them showed intracytoplasmic bile pigment and intranuclear inclusions.

vascular lesions; lymphoproliferative lesions; tumors of the lacrimal gland and optic nerve; and metastatic tumors from the breast, lung, prostate, thyroid, and orbital chloroma in patients with acute myeloid leukemia or chronic myeloid leukemia.

The presence of orbital metastasis in HCC predicts a poor prognosis. In a series of 100 patients by Lubin et al, ${ }^{12}$ the breast was the most common site in $53 \%$ of the patients, followed by the prostate in $12 \%$ and lungs in $8 \%$. The most common clinical findings were limited to ocular motility (54\%), proptosis (50\%), and palpable mass (43\%). The mean survival time after the orbital diagnosis was 20 months. Patients with metastatic carcinoid tumors had the longest mean survival (60 months) and patients with breast cancer had the
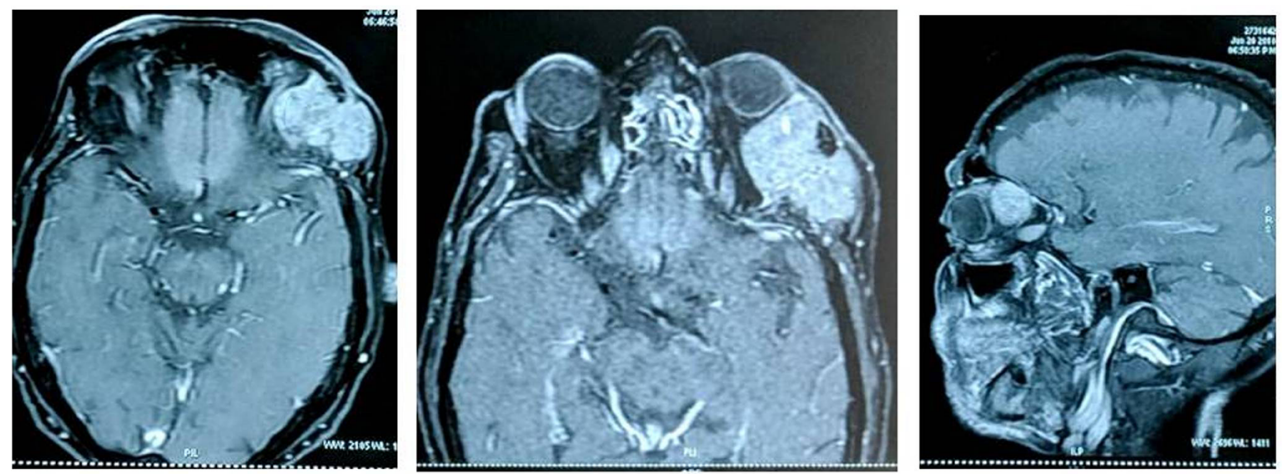

Fig. 1 Magnetic resonance imaging of the brain with orbit showing a heterogeneous lesion in the left frontal lobe causing its destruction with intraorbital and intracranial extensions. 
second-longest mean survival (22 months) after diagnosis of orbital metastasis. In a series of 93 patients of orbital metastasis by Magliozzi et al, ${ }^{2}$ HCC was the primary site in only one patient. Orbital metastases occur unilaterally in more than $90 \%$ of the patients. ${ }^{11}$ To the best of our knowledge, 33 cases have been reported in the literature including case reports and series. ${ }^{2,5-8,813-34}$ Most of the patients were in the sixth and seventh decades of life.
Orbital metastasis, as the initial manifestation of disease, was present in 22 out of 33 patients (-Table 1). Our patient also presented with orbital metastasis as the initial presentation of the disease. A detailed history and thorough ophthalmic and general physical examination must be done in patients with orbital metastasis. Prompt referral to an oncologist is necessary for patients who present with orbital metastasis as the initial manifestation of the disease to rule

Table 1 Cases of orbital metastasis in hepatocellular carcinoma reported in the literature

\begin{tabular}{|c|c|c|c|c|c|c|}
\hline Author & Year & $\begin{array}{l}\text { Number of } \\
\text { cases }\end{array}$ & Age & Gender & $\begin{array}{l}\text { Orbital metastasis } \\
\text { as the first } \\
\text { manifestation of } \\
\text { disease }\end{array}$ & Outcome \\
\hline Lubin et al ${ }^{12}$ & 1980 & 1 & 69 & Male & Yes & Alive \\
\hline Zubler et al ${ }^{13}$ & 1981 & 1 & 64 & Male & Yes & Died after 3 months \\
\hline Wakisaka et al ${ }^{14}$ & 1990 & 1 & 58 & Male & Yes & Died after 11 months \\
\hline $\begin{array}{l}\text { Phanthumchinda and } \\
\text { Hemachuda }{ }^{15}\end{array}$ & 1992 & 1 & 29 & Female & Yes & Not mentioned \\
\hline Kami et al ${ }^{16}$ & 1994 & 1 & 60 & Male & Yes & Died after 3 months \\
\hline Tranfa et al ${ }^{19}$ & 1994 & 1 & 85 & Male & Yes & Not mentioned \\
\hline Schwab et a ${ }^{20}$ & 1994 & 1 & 19 & Male & Yes & Died 1 month \\
\hline Hosokawa et a ${ }^{21}$ & 1994 & 1 & 70 & Male & No & Not mentioned \\
\hline Loo et $a^{22}$ & 1994 & 1 & 71 & Female & Yes & $\begin{array}{l}\text { Lost to follow-up after } \\
3 \text { months }\end{array}$ \\
\hline Font et al ${ }^{23}$ & 1998 & 1 & 79 & Female & Yes & Alive \\
\hline Scolyer et al ${ }^{24}$ & 1999 & 1 & 78 & Male & No & Not mentioned \\
\hline Kim et $\mathrm{al}^{7}$ & 2000 & 1 & 56 & Female & Yes & Died after 2 months \\
\hline Chen et $\mathrm{al}^{25}$ & 2003 & 1 & 69 & Male & Yes & Orbital mass regressed \\
\hline Oida et al ${ }^{26}$ & 2006 & 1 & 72 & Male & No & Died after 4 months \\
\hline Machado-Netto et al ${ }^{17}$ & 2006 & 1 & 57 & Male & Yes & Died after 15 months \\
\hline $\begin{array}{l}\text { Srinivasan and } \\
\text { Krishnanand }\end{array}$ & 2007 & 1 & 76 & Female & Yes & Not mentioned \\
\hline Hirunwiwatkul et al ${ }^{8}$ & 2008 & 1 & 74 & Female & Yes & Died after 2 months \\
\hline Pitts et $\mathrm{al}^{27}$ & 2008 & 2 & $\begin{array}{l}61 \\
47\end{array}$ & $\begin{array}{l}\text { Female } \\
\text { Male }\end{array}$ & $\begin{array}{l}\text { Yes } \\
\text { Yes }\end{array}$ & $\begin{array}{l}\text { Both patients died with } \\
\text { progressive disease }\end{array}$ \\
\hline Fonseca Júnior et a ${ }^{28}$ & 2008 & 1 & 57 & Male & Yes & Died after 15 months \\
\hline Quick et al ${ }^{6}$ & 2009 & 1 & 52 & Male & No & Alive 20 months \\
\hline Kolarević et al ${ }^{29}$ & 2011 & 1 & 70 & Male & No & Died after 6 months \\
\hline Mustapha and Madachi ${ }^{30}$ & 2011 & 1 & 25 & Male & No & Not mentioned \\
\hline Guerriero et a ${ }^{31}$ & 2011 & 1 & 45 & Male & No & Not mentioned \\
\hline Eldesouky et al ${ }^{18}$ & 2014 & 6 & $\begin{array}{l}\text { Range } \\
47-70 \\
\text { Mean } \\
\text { age } 60.2 \\
\text { years }\end{array}$ & Male & 3 cases & $\begin{array}{l}\text { Survival of five cases } \\
\text { ranged between } 8 \text { and } \\
13 \text { months with a mean } \\
\text { of } 10.2( \pm 2.3) \text { months. } \\
\text { One patient was receiv- } \\
\text { ing treatment (diag- } \\
\text { nosed for } 6 \text { months) }\end{array}$ \\
\hline Téllez-Villajos et al ${ }^{32}$ & 2015 & 1 & 70 & Female & No & Alive at 4 months \\
\hline Madabhavi et $a^{33}$ & 2020 & 1 & 72 & Male & Yes & $\begin{array}{l}\text { Alive at } 7 \text { months with } \\
\text { stable disease }\end{array}$ \\
\hline Protopapa et a ${ }^{\mid 34}$ & 2020 & 1 & 53 & Male & Yes & $\begin{array}{l}\text { Discharged after } \\
\text { radiotherapy with little } \\
\text { improvement }\end{array}$ \\
\hline
\end{tabular}


out primary at the earliest. Radiological investigations such as computed tomography and MRI are the principal means of evaluating orbital lesions. The potential risks of performing a biopsy of an orbital mass such as visual loss, bleeding, and diplopia, should always be weighed against the potential benefits, evaluating whether the management options are going to change as a result of the biopsy.

The intent of treatment in patients presenting with orbital metastasis is palliative as such metastasis suggests a hematogenous spread of disease. The aim of the treatment is to maximize the quality of life of such patients and to preserve visual function if possible. Radiotherapy is the mainstay of treatment in such patients as it will cause shrinkage of the lesion, control of symptoms, and visual preservation. Surgical resection is appropriate only in selected patients.

Orbital metastasis in HCC is rare. A high index of suspicion is required as proptosis and diplopia were the first manifestations of disease in the index case. Clinicians should be aware of such presentations. Prognosis in such patients remains dismal. The treatment should focus on providing relief from symptoms of the illness. Radiotherapy plays an important role in downsizing the lesion and symptom control.

\section{Declaration of Patient Consent}

The authors certify that they have obtained all appropriate patient consent forms.

\section{Funding \\ None.}

\section{Conflict of Interest}

None declared.

\section{References}

1 Ahmad SM, Esmaeli B. Metastatic tumors of the orbit and ocular adnexa. Curr Opin Ophthalmol 2007;18(5):405-413

2 Magliozzi P, Strianese D, Bonavolontà P, et al. Orbital metastases in Italy. Int J Ophthalmol 2015;8(5):1018-1023

3 Bonavolontà G, Strianese D, Grassi P, et al. An analysis of 2,480 space-occupying lesions of the orbit from 1976 to 2011. Ophthal Plast Reconstr Surg 2013;29(2):79-86

4 Allen RC. Orbital metastases: when to suspect? When to biopsy? Middle East Afr J Ophthalmol 2018;25(2):60-64

5 Srinivasan R, Krishnanand G. Cytologic diagnosis of metastatic hepatocellular carcinoma presenting as an orbital mass. A case report. Acta Cytol 2007;51(1):83-85

6 Quick AM, Bloomston M, Kim EY, Hall NC, Mayr NA. Complete response to radiation therapy of orbital metastasis from hepatocellular carcinoma. World J Gastroenterol 2009;15(47):6000-6003

7 Kim IT, Na SC, Jung BY. Hepatocellular carcinoma metastatic to the orbit. Korean J Ophthalmol 2000;14(2):97-102

8 Hirunwiwatkul P, Tirakunwichcha S, Meesuaypong P, Shuangshoti S. Orbital metastasis of hepatocellular carcinoma. J Neuroophthalmol 2008;28(1):47-50

9 Valenzuela AA, Archibald CW, Fleming B, et al. Orbital metastasis: clinical features, management and outcome. Orbit 2009;28(2-3):153-159

10 Shikishima K, Kawai K, Kitahara K. Pathological evaluation of orbital tumours in Japan: analysis of a large case series and 1379 cases reported in the Japanese literature. Clin Exp Ophthalmol 2006;34(3):239-244
11 Shields JA, Shields CL, Brotman HK. Carvalho C, Perez N, Eagle RC Jr. Cancer metastatic to the orbit: the 2000 Robert M. Curts lecture. Ophthal Plast Reconstr Surg 2001;17(5):346-354

12 Lubin JR, Grove AS Jr, Zakov ZN, Albert DM. Hepatoma metastatic to the orbit. Am J Ophthalmol 1980;89(2):268-273

13 Zubler MA, Rivera R, Lane M. Hepatoma presenting as a retro-orbital metastasis. Cancer 1981;48(8):1883-1885

14 Wakisaka S, Tashiro M, Nakano S, Kita T, Kisanuki H, Kinoshita K. Intracranial and orbital metastasis of hepatocellular carcinoma: report of two cases. Neurosurgery 1990; 26(5):863-866

15 Phanthumchinda K, Hemachuda T. Superior orbital fissure syndrome as a presenting symptom in hepatocellular carcinoma. J Med Assoc Thai 1991;74(12):679-682

16 Kami H, Wada M, Matsuura T, et al. Case of hepatocellular carcinoma with an orbital metastasis as the initial symptom [article in Japanese]. Nippon Naika Gakkai Zasshi 1994;83(4):622-624

17 Machado-Netto MC, Lacerda EC, Heinke T, Maia DC, Lowen MS, Saad ED. Massive orbital metastasis of hepatocellular carcinoma. Clinics (São Paulo 2006;61(4):359-362

18 Eldesouky MA, Elbakary MA, Shalaby OE, Shareef MM. Orbital metastasis from hepatocellular carcinoma: report of 6 cases. Ophthal Plast Reconstr Surg 2014;30(4):e78-e82

19 Tranfa F, Cennamo G, Rosa N, De Rosa G, Boscaino A, Bonavolontà G. An unusual orbital lesion: hepatoma metastatic to the orbit. Ophthalmologica 1994;208(6):329-332

20 Schwab L, Doshi H, Shields JA, Kagame K, Chana H. Hepatocellular carcinoma metastatic to the orbit in an African patient. Ophthalmic Surg 1994;25(2):105-106

21 Hosokawa C, Kawabe J, Okamura T, et al. Usefulness of 99mTc-PMT SPECT and 18F-FDG PET in diagnosing orbital metastasis of hepatocellular carcinoma [article in Japnese]. Kaku Igaku 1994;31(10):1237-1242

22 Loo KT, Tsui WM, Chung KH, Ho LC, Tang SK, Tse CH. Hepatocellular carcinoma metastasizing to the brain and orbit: report of three cases. Pathology 1994;26(2):119-122

23 Font RL, Maturi RK, Small RG, Garcia-Rojas M. Hepatocellular carcinoma metastatic to the orbit. Arch Ophthalmol 1998;116(7):942-945

24 Scolyer RA, Painter DM, Harper CG, Lee CS. Hepatocellular carcinoma metastasizing to the orbit diagnosed by fine needle aspiration cytology. Pathology 1999;31(4):350-353

25 Chen PH, Po HL, Lin YJ, Hseuh IH, Huang JK. Painful ophthalmoplegia as the initial manifestation of hepatocellular carcinoma: a case report and literature review. Acta Neurol Taiwan 2003;12:93-96

26 Oida Y, Ohtani Y, Dowaki S, et al. Hepatocellular carcinoma metastatic to the orbit: a case report. Tokai J Exp Clin Med 2006;31(1):7-10

27 Pitts J, Chang CH, Mavrikakis I, Shaikh A, Rootman J. Hepatocellular carcinoma presenting as orbital bone metastasis. Ophthal Plast Reconstr Surg 2008;24(6):477-479

28 Fonseca Júnior NL, Frizon L, Paves L, Wolosker AM, Manso PG. An unusual orbital metastatic lesion: the only finding in a case of hepatocellular carcinoma: case report [article in Portuguese]. Arq Bras Oftalmol 2008;71(6):865-867

29 Kolarević D, Tomasević Z, Boricić I, et al. Metastasis of hepatocellular carcinoma presented as a tumor of the maxillary sinus and retrobulbar tumor. Vojnosanit Pregl 2011;68(4):359-362

30 Mustapha SK, Madachi DA. Orbital metastasis of hepatocellular carcinoma: a case report. West Afr J Med 2011;30(4):305-307

31 Guerriero S, Infante G, Giancipoli E, et al. Hepatocellular carcinoma metastasis to the orbit in a coinfected HIV+ HBV+ patient previously treated with orthotopic liver transplantation: A case report. Case Rep Ophthalmol Med 2011:549270

32 Téllez-Villajos L, Maroto-Castellanos M, Lledó-Navarro JL, López-Durán S, Moreira-Vicente V, Albillos-Martínez A. Orbital 
metastasis from hepatocellular carcinoma. Rev Esp Enferm Dig 2015;107(4):231

33 Madabhavi I, Ks S, Dharmarajan Lethika R, et al. Intraconal metastasis leading to diagnosis of hepatocellular carcinoma. Middle East J Dig Dis 2020;12(1):48-51
34 Protopapa MN, Lagadinou M, Papagiannis T, Gogos CA, Solomou EE. Hepatocellular carcinoma: An uncommon metastasis in the orbit. Case Rep Oncol Med 2020:7526042 